\title{
慢性下顎骨骨髄炎の一症例について
}

\author{
熊本大学医学部付属病院歯科口腔外科（指導：田縁昭助教授）
}

児玉园昭 - 寺脇博

（本論文の要旨は第32回九州歯科学会総会で報告した。）

\section{A Case of the Mandibular Osteomyelitis}

By

Kuniaki Kodama. Hiroshi Terawaki

Clinic of Dento-oral surgery (Director: Ass. Prof. Akira Taen)

Faculty of Medicine, Kumamoto University, Kumamoto, Japan

The author experienced the patient, a 69-years-old-man, with chronic osteomyelitis of the mandible. It was said that the patient had allergy for the antibiotics, and he was no given it.

We tried to examinate the allergy test for the antibiotic agents (Carb enicillin, Chloramphenicol, Lincomycin, Tetracycline and Oleandmycin), but we could not recognize it. For this case, we did medicinal substances therapy and surgical radical operation, and he was cured.

The patient today, a year after the osteomyelitis therapy, is alive and free of the disease.

\section{緒 言}

口腔領域における化膿性疾患は，従来より相当高い䍜 患率を示している。 その原因は，大部分が㐘性疾患の感 染によるあのである。 その処置にあたっては、ペニシリ ンの出現後一連の抗生剂の開発により比較的容易よなっ た。したがって顎炎の急性期における療法は，めざまし い成果が得られ，急性顎炎とその併発症に上る生命の危 険を感ずることは少なくなった。しかしながら種々の理 由で抗生剂の使用が制限されると，昔日の如き状態とな り，単純な顎炎も急速に進行して重篤な症状を呈するこ とあある。

最近われわれは，69才の男性で単純な顎炎を，薬物ア レルギーが発現したという理由のために，充分なる抗生 剤の投与がほとんど行われず，慢性下顎骨髄炎まで移行 したと思われる症例に遭遇した。本症例に対し，外科的 根治手術亡, 強力な化学療法により良好な結果が得られ たので，その概要について報告する.

症例

患者:間 $\bigcirc$ 助 男性 69才
初 䛦: 昭和46年11月18日

主 訴：左側碩部及び左側下顎骨骨体部の腫脹並びに 瘦孔形成

既往歴：昭和43年脳軟化症に䍜患 昭和46年そ径ヘルニアに罹患

家族歴：特記事項はない

現病歷：昭和46年 9 月 5 日 左側下顎骨体部の疼痛 と 腫脹を自覚したため，某歯科を受診し抗生剂の投与を受 けた。しかし皮疹の発現があり，ただちに投与を中止し た。 その後, 疼痛, 腫脹がなお持続するため左側下顎臼 歯の抜霜を受けた。数日後, 左側頣孔下部付近の皮㞕に 瘦孔形成が認められたため，某歯科に転医した。そこで 抗生剂の感受性テストを行なったところ，ほとんど陰性 を示したので，抗生剤の投与を受けた。 それと共に左側 願部の切開排膿と残余の左側下顎小曰歯の抜歯を受け た.しかほ切開創は，閉鎖せず排膿が持続するため，さ らに本学医学部付属病院整形外科を受診し, 当科へ紹介 されたものである。

現 症：体格栄養中等度で，そ径へルニアがある以外 


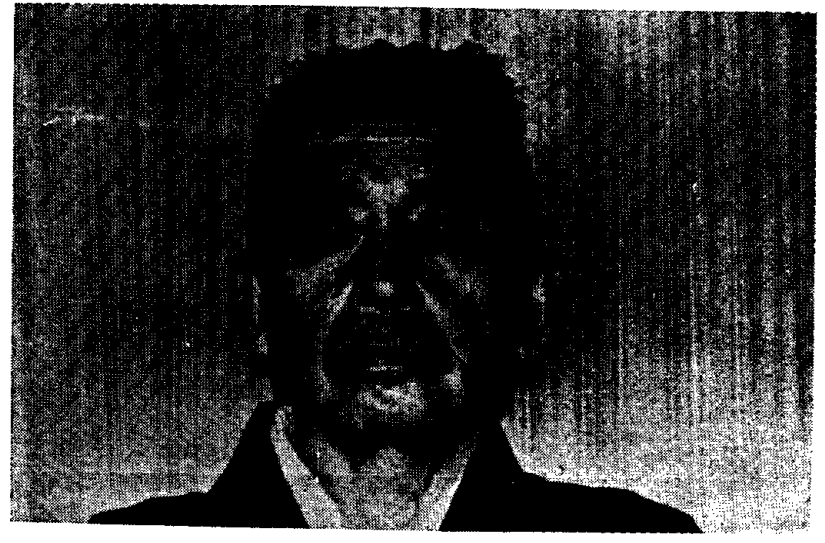

写真 1 。初診時顔貌所見

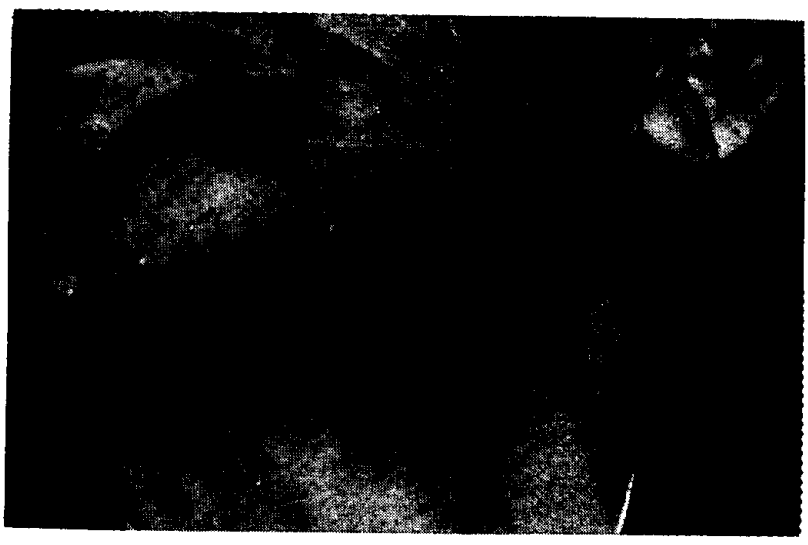

写真 2 . 初診時口腔外所見 願孔下部に瘦孔形成が認められる.

に全身所見には異常は認められない，顔貌は非対称性 で, 左側匵部より左側下顎骨体部に，軽度の発赤を伴っ た硬結性腫脹が認められた．左側願孔下部付近に 4 個の 円形，えんどう豆大の瘦孔形成が認められ，同部瘻孔よ り帯黄色，粘椆の濃汁の排出があり，その周囲の皮膚は

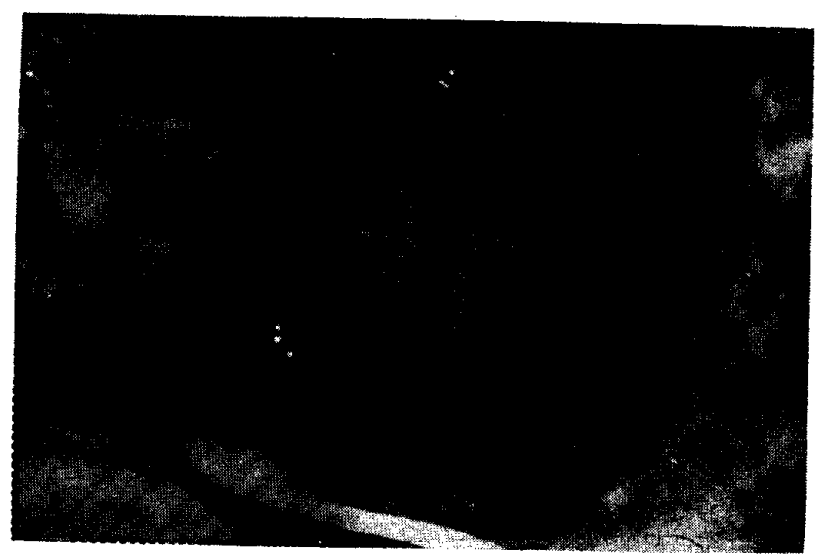

写真 3. 初診時口腔内所見 小曰歯部及び智歯部の歯肉頉移行部に瘦孔形 成が認められる。
暗赤色を呈していた．左側顎下リンパ節は，えんどう豆 大の硬結性腫脹があり軽度の圧痛が認められた，左側下

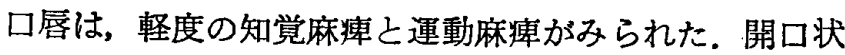
態は三横指で， $\frac{7 \sim 5}{7 \sim 4} \mid \frac{67}{3 \sim 7}$ は久損し，左側下顎小曰歯部 亡智歯部の歯肉頓移行部に，えんよ゙う豆大の発赤を伴う 2 個の瘻孔形成が認められ，同”部より排膿’が認められ た、レ線所見では，左側願部より智歯部にかけクルミ大

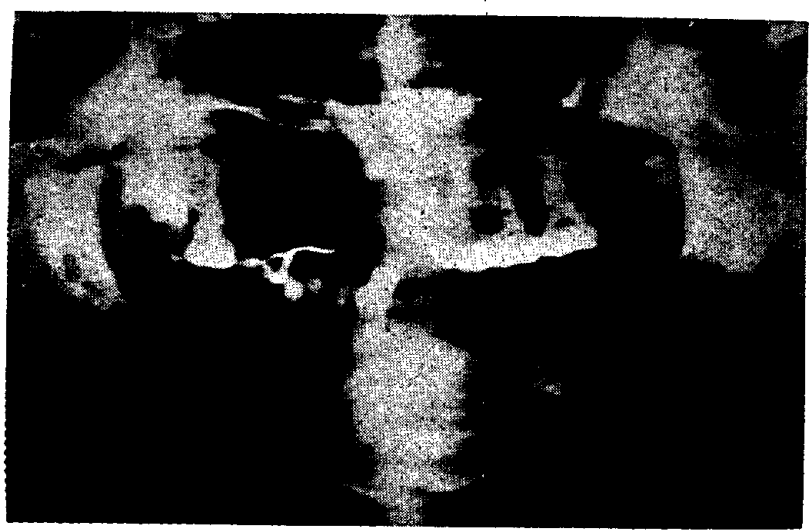

写真 4. 初診時レ線所見

の雲影状を示すレ線透過像が認められ，周囲にはレ線透 過性の層があり正常骨之境界され，いわゆる死骨枢の所 見を呈していた。

以上の臨床所見より慢性下顎骨骨䯣炎之診断した。

\section{処贯及ひ样逗}

初診時患者には薬物アレルギーの既往があるとされた ために，われわれが日常使用している，カルベニシリン , リンコマイシン, クロラムフェニコール; 複合抗生物 質 $(\mathrm{TC}+\mathrm{OM})$ の皮内テストを行なった。 カルベニシ リンはカルベニシリンナトリュウム $300 \mathrm{mg}$ (力価), 塩 化ナトリュウム $9 \mathrm{mg}$ を日局注射用蒸留水 $1 \mathrm{ml}$ によかし たものを使用し，他は原液を用いた．右側前腕皮庿に乱 刺法により行ない，15分および30分後の変化で判定を行 なった。

その結果, 発赤, 浸潤, 小水疱などの変化は認められな かった. 初診時および入院時, 術前之計 3 回口腔内, 口 腔外の瘦孔よりの膿汁を培養し菌検出を試みたが検出不 能であった．第 2 病日よりカルベニシリン $10 \mathrm{~g} 6$ 時間 ごとに静注を行ない, 同時にリンコマイシン600 mgの筋 注を行なった。投与後約一週間で願部皮虚の瘦孔は2個 か澗鎖し，排膿も減少した。また顎骨骨体部の登赤， 腫脹が減少したので腐骨除去手術を施行した。昭和46年 11月30日，全身麻酔のあとに，口腔外より左側下䫚骨下 縁の約 $I \mathrm{~cm}$ 内側の, 左側頤部および顎下部皮膚に下顎 
表 1 臨床検查成績

\begin{tabular}{|c|c|}
\hline ヘモグロビン值 & $14.1 \mathrm{~g} / \mathrm{dl}$ \\
\hline 赤 血 球 数 & $409 \times 10^{4} / \mathrm{mm}^{3}$ \\
\hline 血 小 板 数 & $22.6 \times 104 / \mathrm{mm}^{3}$ \\
\hline ヘマトクリット值 & $42 \%$ \\
\hline 白 血 球 数 & $6900 / \mathrm{mm}^{3}$ \\
\hline 好塩基球 & $1 \%$ \\
\hline 好酸球 & $0 \%$ \\
\hline 好中球 桿状核 & $25 \%$ \\
\hline 分葉核 & $40 \%$ \\
\hline リンパ球 & $27 \%$ \\
\hline 単 球 & $7 \not 6$ \\
\hline カルシュウム & $4.5 \mathrm{mEq} / \mathrm{dl}$ \\
\hline 無機リン & $3.15 \mathrm{mg} / \mathrm{dl}$ \\
\hline 血 糖 & $93 \mathrm{mg} / \mathrm{dl}$ \\
\hline 尿素窒素 & $15.5 \mathrm{mg} / \mathrm{dl}$ \\
\hline 尿 酸 & $6.0 \mathrm{mg} / \mathrm{dl}$ \\
\hline 総コレステロール & $145 \mathrm{mg} / \mathrm{dl}$ \\
\hline 総 蛋 白 & $7.65 \mathrm{~g} / \mathrm{dl}$ \\
\hline アルブミン & $3.65 \mathrm{~g} / \mathrm{dl}$ \\
\hline 総ビリルビン & $0.7 \mathrm{mg} / \mathrm{dl}$ \\
\hline アルカリホスフアターゼ & $8 \quad$ K. A.u \\
\hline $\mathbf{L} \mathbf{D} \mathbf{H}$ & W.u \\
\hline GO $T$ & K. u \\
\hline ナトリュウム & $136 \mathrm{mEq} / 1$ \\
\hline カリュウム & $4.4 \mathrm{mEq} / 1$ \\
\hline クロール & $100 \mathrm{mEq} / 1$ \\
\hline 酸性ホスフアターゼ & 4. $0 \quad$ K. u \\
\hline
\end{tabular}

下縁に沿って約 $15 \mathrm{~cm}$ の皮切を加え，下顎骨を露出させ た。露出した下顎骨の小曰歯部之智霜部では，顿側の骨 は菲薄化し，一部では腐骨周团の不良肉芽組織が露出し た所見を示した。また，腐骨周囲の下顎骨体部及び下顎 下縁に加りて厚さ約 $2 \mathrm{~mm}$ の添加骨が多量に認められ た．添加骨を鋭匙にて除去した後，左側小田蒾部及び智 米部の菲薄化した骨を除去し，腐骨の摘出を行なった。 左側㲊部之智歯部の腐骨を除去した摘出腔は下歯槽管に より連接していた，口腔内で㿉孔を形成している小柬 部之智歯部の歯肉は切除し， 口腔内外の手術創は共に閉 銷創とした. 手術後の処置並びに退院までの経過は表 2 に示す如くである．熱型は術後4 日目頃より順調に下降 し正常になった，術後約一週間で手術創の腫脹はほぼ消 失したが，創部皮唐の発赤は比較的長く残り約三週間後

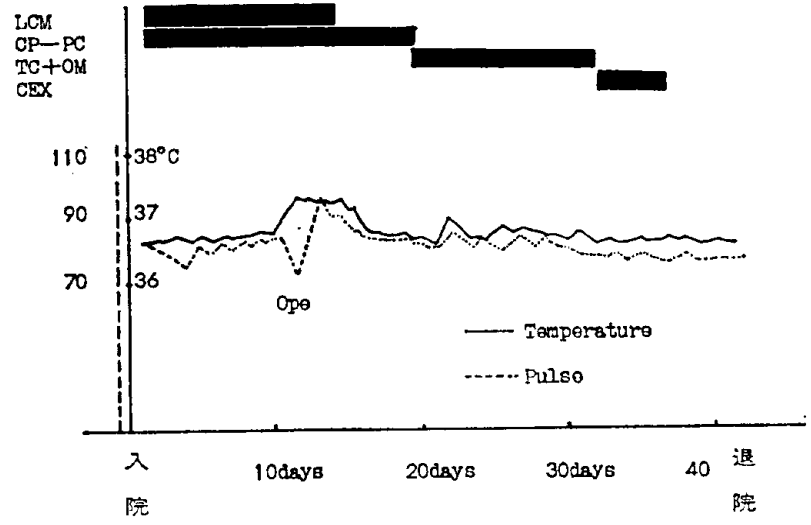

因1.処置並びに経過

に正常皮有の色調を呈するようになった，乙の時点で抗 生剂の投与を中止し術後42日で退院した. 現在一年を経 過したが炎症の再燃は全く認められない。

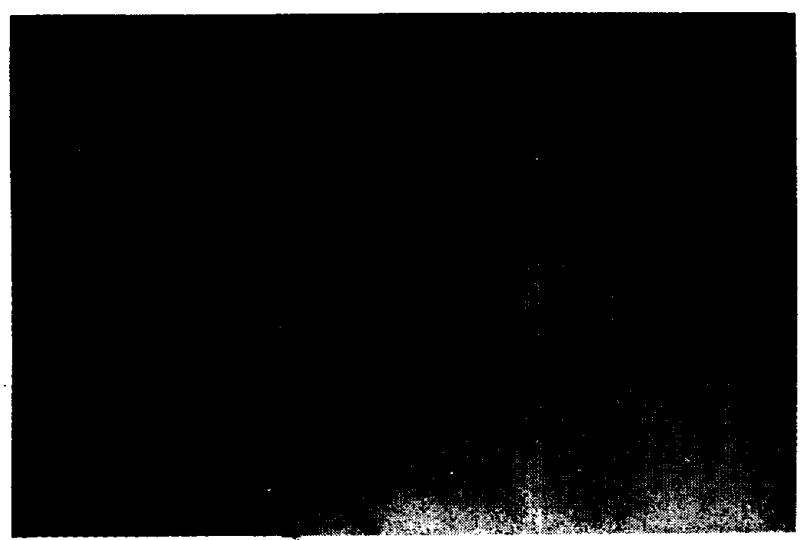

写真 5 . 術後一年目の口腔外所見

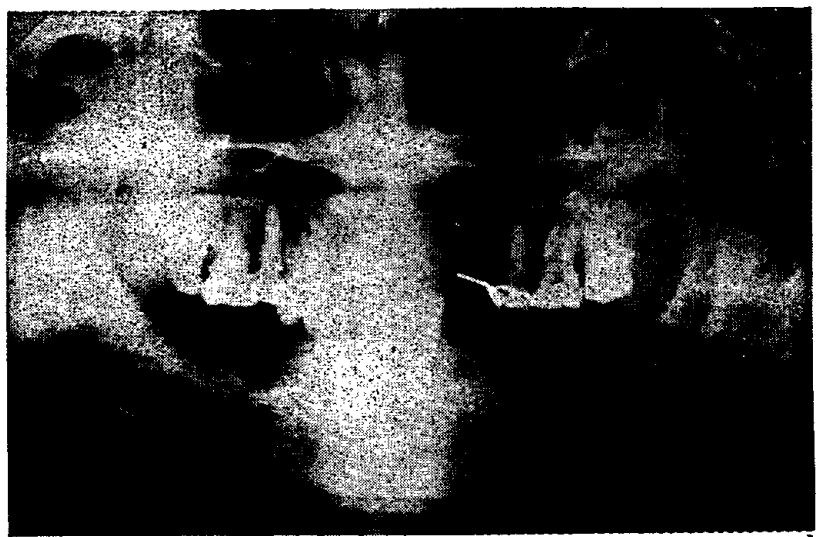

写真 6 .術後一年目のレ線所見

考

察

顎の炎症の原因は澦目身に原因をもつもの，隣在組織 の炎症拡大によるるの，及び身体他部よりの血行感染に よるものに大別されるが，その大部分は顎自身に原因を あつあのであり，多くが歯性感染によるあのである。 
佐藤 $(1967)^{1)}$ は歯性感染のうちで, 主なるものは根尖 性感染症，辺縁性炎症，抜歯創代対する感染等をあげて いる，また顎炎が慢性化する团子としては，Kbosla (19 71)2）は急性期における処置の遅れ，腐骨の不完 全な除 去, 抗生剂の選択や投与期間の錯詥, 不明確な最初の診 断などを挙げている．先人の報告をみる己特殊な細菌が 感染した例334）あみられ，また塩田（1967）占）特殊な細 菌は見出されず，長期間にわたる抗生剂の反復投与の治 療が薬剤耐性菌育成という逆効果になったのではないか と思われる症例を報告している.

本報告例における感染経路は左側下顎小曰歯の根尖病 巣より之考えられ，特に特異なるのではなかった。しか し同部に急性炎症があるにあかかわらず，抗生剤の投与 により皮疹が生じたため投与を中止せざるを得なくな り，またこの時期に同部の蒾牙を抜去することにより， 炎症をさらに拡大し慢性顎炎认移行したと考えられる。 本報告例の如く抗生剂の投与により，偶発的に皮聄が発 現し，これをあって薬物アレルギーがあるとされたため ，抗生剂の投与が行なわれず単純な顎焱から顎骨骨䯣炎 まで進展した之する報告例は，われわれの調查した限り では涉椫し得なかった. 類似した報告例としてはRonald (1963) $)^{6)}$ の報告に見られる。乙症例は術 後観 察が充 分行なわれず，また患者自身アルコール中毒症であった ため，充分なる投薬管理が行なわれず，慢性下類骨骨髄 炎にまで進行した例を報告している。田縁（1971)7， 菊 地 (1966)8）はステロイド剂単味投与によって易感染 性となり骨髄炎が併発した例を報告している。

本報告例の治療にあたり，われわれは抗生剤投与時に 毎常行なわれる楽物アレルギーテストを行なった。薬物 テストには，乱切法，乱刺法，および皮内試験（狭義） などがあり9，本報告例では乱刺法を行なった。，その結 果15分, 30 分後, 発赤, 浸潤, 小水疮等の変化はみられ なかった。とのととから既往にある皮信は，その時期に 患者の全身的ななに灺の因子があり，その結果, 皮㷌 が生じたものと思われる. 感染症の治療に際して抗生剂 の投与は十分に，また慎重でなければならないが，全て の抗生剂が使用不能となる場合は，まず考えられないた め，注意深く使用可能な薬剤を選定すべきであろう.

骨髄炎の臨床診断は，臨床症状，レ線所見にて行なわ れているようである。臨床症状としては，一般に独特の 症状を経過した後，慢性期汇達すると自発痛，圧痛は減 少し, 口腔内外に多数の瘦孔を形成し, 膿汁を常に排出 するという症状を呈するようになる，しかし江草 (1970 )$^{10)}$ ，二宮（1969)11)は最近の骨䯣炎の傾向は，起炎菌の
毒力の低下及び感染個体の抵抗力の增加により亜急性の あのが増加し，慢性的に発症し慢性的に経過するるのが 多くなっていると述へている。線的には Archer（196 8)12)によれば急性期においては変化は認められず，数週 が経過するとレ線透過性が認められるようになり，さら にレ線透過部は互いに合体し，虫が喰ったあとのような 斑状の様相を呈すると述へてている．佐藤 (1967)1) は， そのような状態を大理石紋様状と呼んでいる．さらに佐 藤は慢性下顎骨骨䯣炎を臨床的括よびレ線的に急性より 慢性に移行した遷延性，骨の肥厚を伴う壊瘟性，骨中に 大きな欠損がみられる潜行性，骨紋理の变化なく骨欠損 むないむの渗出性，硬化骨部陰影を認めるすの增殖性の 5 種類に分類している. 本報告例の場合，レ線所見では 境界明瞭な腐骨形成を示すクルミ大のレ線透過像がみら れ病巣部の骨稜は健側に比し不明瞭であった。臨床的に は，口腔内外に瘻孔を形成し，持続的な排膿が認められ た。 上記の分類では慢性遷延性下顎骨骨髄炎にあてはま る之思われる。

また塩田（1967）占）は臨床所見，レ線所見だけに頼ら ず臨床検查，すなわち末梢血液像や血液生化学検查など により，症状を把楃する補助診断屯意義があると述へて いる：その報告の中で，塩田は骨の基質形成関与する と思われる血清総蛋白, 血清アルカリフォスファターゼ 等, 骨新生や破壊の際，之の变化が密接な関係にあり， これらを臨床並びにレ線所見と照合することによりよ り正確な病変経過の把握ができると述へている．本報告 例における末梢血液像及び血液生化学検查では俥度の核 の左方移動が認められるのみで，その他の変化は認めら れなかった。一年後の検査結果では核の左方移動は消失 しそのの他の検查結果す正常值を示していた。

本報告例の如き顎骨骨䯣炎の治療にあたっては化膿性 疾患である⿸尹口，化学的療法之外科的療法による手段が 一般に行なわれている。抗生剤の使用にあたっては，病 原菌の感受性検查結果により抗生剤の選択を行なう必要 があるが，本報告例の場合，初診時及び術前二回計三 回, 口腔肉、口腔外の煝孔よりの膿汁を培養し菌検出を 試みたが、いずれあ検出不能であった.しかし一般に口腔 内感染症の多くがブ菌によることが多いため，中範囲か ら広範囲抗菌スペクトラムを有する抗生物質を検查結果 を待たずして臨床診断のもとに投与が行なわれている。 しかし浜田 (1968)13), 吉田 (1968)14)の報告にあみられ るように，感染菌が薬剂耐性を持っている場合など，特 に治瘉遅延の原因となり慢性炎症を拡大する場 合があ る. 本報告例では比較的耐性菌の少ない之されるカルべ 
ニシリン之，顥領域に比較的高い組織内濃度が保たれる とされるリンコマイシンの投与を行なった。その結果 5 日目頃より㾇孔よりの排膿及び皮膚の発赤の症状は籍快 した。

本報告例の如く浖骨を形成した影炎においては平川 1960)15）は蒋物療法単独では，その限界を越えたるの上 みなさなければならず，さらにこのような腐骨を形成し た顎炎をすみやかに解決するにはｉ）腐骨あるいは変性 骨を除去すること，ii）その結果残された骨創腔の組織化 が順調に進むための障害を除くこと，iii）既存病原菌の 抑制の三点をあげて薬物療法単独の限界を示している.

本報告例では耐性の少いと考えられる新らしい広範囲 スペクトラムを有する抗生物質を比較的大量に投与を行 ない症状の緩解を得た，投与後約一週間で㺏孔周囲の皮 痛の発赤および㿉孔よりの排膿が減少したので, 平川の いう如き腐骨除去手術を施行し，骨創腔の組糡化を助長 し，同時に瘦孔周囲の不良肉芽組織を完全に除去し，さ らに術後にも強力な化学療法を行ない良好な結果を得 た.

\section{桔}

1.69才の男性で偶発的に発現したと思われる皮珳によ って，薬物アレルギーがあるとされ，抗生剤の投与を 受けないまま，巣純な顎炎から慢性下靧骨骨髅炎に移 行した症例に遭遇した。

2. 本報告例に対し，充分慎重に抗生剂のテストを行な って, 強力な化学療法の後に外科的根治療法を行ない 良好な結果が得られた。

（御指導，御校閲を睗わった田縁昭助教授に深謝する）

\section{女 憱}

1. 佐藤伊吉 : 実地口腔外科, 5 版, 日本菌科評論社
東京, 1967.

2. Kbosla. M : Evaluation of three techinques for the moragement of postextraction third molar sockets, os. om. op. $31: 649-658,1971$.

3. 坂井 浩・他：2 ケ年余の経過を辿った慢性下顎骨 骨䯣炎の一例，日口外誌 $17: 352 ， 1968$.

4.小林一郎・他：慢性放線菌性下額骨骨髄炎の一例, 日口外誌 $12: 180-185,1966$.

5. 塩田 覚・他：下顎骨切除部に骨移植した慢性䋶骨 骨䯣炎の一治験例, 京大口腔外科紀要 7：35一 46, 1967.

6. Ronald. F : Osteomyelitis of the Mandible Report of a case, os. om. op. 16:914-918, 1963.

7. 田縁 昭：ステロイド系楽剂投与により下顎骨骨髄 炎の合併した症例，歯界展望 37：457-460，1971.

8. 菊地 晃・他：最近の化膿性骨䯣炎症例の検討, 医寮 $19: 224-225,1966$.

9. 犬塚貞光: 新外科学概説, 医歯薬出版, 東京, 1970 .

10. 江草敬治：最近の化膿性骨髄炎について，倉敷中央 病院年報 $38: 212-225,1970$.

11. 二宮昭雄：最近の顥骨骨髅炎の一傾向, 矤療 22 : 263, 1969.

12. Archer. W. H : 口腔外科学, 医荘薬出版, 東京, 1968. 訳, 河野庸雄

13. 浜田 ・他：下顎骨切除を行なった下係骨骨䯣 炎, 日口外誌 $17: 352-353,1968$.

14. 吉田恒丸：教室に於的る化膿性骨䯣炎の観察, 整形 外科 $19: 33-37,1968$.

15. 平川正輝：䫑炎の処理について, 日ロ外誌 6 ： $220-226,1960$. 